\title{
Social Work Postgraduate Education in Brazil: there is a stumbling block on the way
}

\author{
Jussara Maria Rosa Mendes \\ Federal University of Rio Grande do Sul (UFRGS)
}

Andreia Mendes dos Santos

Pontifical Catholic University of Rio Grande do Sul (PUCRS)

\section{Rosangela Werlang}

Federal University of Rio Grande do Sul (UFRGS)

Social Work Postgraduate Education in Brazil: ther e is a stumbling block on the way

Abstract: This paper discusses the Brazilian postgraduate background through the National Postgraduate Plans (PNPGs). They comprise five plans developed from 1974 to 2011, the latest one being in force until 2020. It presents a reflection about the development of postgraduate programs in Social Work aiming to understand how much the changes and present demands, of neoliberal approach and highlighted in the latest PNPGs, affect Social Work activities, especially concerning the continuous search for quality, excellence and consolidation of an ethical-political-professional project.

Keywords: Postgraduate. National Postgraduate Plans. Social Work. 


\section{Introduction}

This paper deals with the implementation and development of Social Work Postgraduate Programs in Brazil, seeking to understand its development in the context of the National Postgraduate Plans (Planos Nacionais de Pós-Graduação - PNPGs). In this regard, it can be seen that Brazilian postgraduate courses have grown considerably in number and quality, especially via the National Postgraduate System and support agencies, whose articulated efforts have ensured good quality education of teachers, researchers and other professionals to work either in higher education institutions or other areas. It is in this context that Postgraduate in Social Work has developed, providing new insights to the practice of this profession and consolidating and qualifying its ethical-political-professional project. Furthermore, it consists of the expression of the accomplishments in this field, resulting from the joint work developed by organizational institutions of this category: the Brazilian Association for Education and Research in Social Work (ABEPSS), National Council of Social Work (CFESS), National Executive of Social Work Students (ENESSO). However, despite all these advancements, threats of discontinuity surround the development agencies, such as the Coordination for the Improvement of Higher Education Personnel (CAPES) and the National Council for Scientific and Technological Development $(\mathrm{CNPq})$, as a result from the global worsening of economic, social, cultural and ethical crisis. Reduced resources to public research began to be shared with the private sector, aiming to enhance innovation, entrepreneurship and to increase the competitiveness and productivity of economic activities.

\section{National postgraduate policies as described in the postgraduate plans}

Brazilian postgraduate programs were created to expand and complete college education and the academic-professional training, to boost research activities, although they already existed in connection with the academic training and developed by institutes. So, research was fostered through the formal academic structure and logistics and by its incorporation to postgraduate programs. Two strong trends marked the Brazilian postgraduate history: the European approach, which was adopted in 1930 by the School of Law of the University of Rio de Janeiro, in the National Philosophy Faculty and in the University of São Paulo; and the NorthAmerican one, in the 1950s, when agreements began to be made between the United States and Brazil (SANTOS, 2003). At that time, the government had an interest in developing specialized workforce as a prerogative for the development of the country, and in this context the Statute of Brazilian Universities was created through Decree no. 21.321 of June 18,1946 . It pointed to postgraduate programs with the specific purpose of professional specialization. In principle, without any external regulation, Brazilian postgraduate courses had little impact on higher education and because of the strong cultural subordination, science models were reproduced without a national identity, without international recognition.

It is necessary to recognize that postgraduate education in Brazil was strengthened during the period of military dictatorship, although it did not include research in its core activities. In 1968, the Brazilian government, pushed by social and student movements, demanded a deep reform in higher education. Supported by the North-American approach, the academic chair model ${ }^{1}$ was replaced by the departmental organization, fulltime teachers were hired, and sequential courses were replaced by the credits system. It was also created master and doctoral courses, similar to the American structure (BALBACHEVSKY, 2010).

The creation of foundations such as CNPq (April 17, 1951) and CAPES (July 11, 1951) in the third month of Vargas' government, identified as a strategic government issue the implementation of these foundations, becoming essential for the establishment of an institutional system focused on the scientific and technological development of the country. In this new scenario, with formal recognition of academic titles, a new emphasis was given to research and the expansion and consolidation of stricto sensu postgraduate education (master's or doctoral degrees), and a system of evaluation and qualification of the courses was developed by the scientific community, which quickly resulted in the proliferation of postgraduate programs in Brazilian universities. In this process, CNPq and CAPES became spaces of excellence to ensure the technological development in the country. To the National Postgraduate Council was assigned in 1974 the responsibility to create the PNPGs (I, II, III, IV, V), which describe and define guidelines, strategies and goals to enhance postgraduate and research policies in Brazil.

The first National Postgraduate Plan (PNPG) was published in December 1974 and implemented between 1975 and 1979. The object of the referred plan was the postgraduate activities developed by higher education institutions as well as research institutions. Among the proposed works is the integration of research and teaching, the qualification of human resources for other educational levels and also for society as a whole. At that time, it comprised 158 areas of study for master's degree and 89 areas for doctorate, all of them recognized 
by the Federal Education Council (BRASIL, 2016a). Some funding agencies and bodies also began to deal with personnel's education, among them the National Bank for Development (BNDE), the National Council for Scientific and Technological Development (CNPq) and the Financing Agency for Studies and Projects (FINEP).

The PNPG I diagnosed the Brazilian postgraduate education in some aspects considered more sensitive, which served as the basis for the guidelines for the execution of its policies. The diagnosis specifically pointed to the need for postgraduate stabilization both from the financial and institutional point of view as well as administrative, and the general postgraduate objectives and guidelines put emphasis on the professional education of higher education teachers and qualification of researchers for the development of research centers.

The PNPG II was developed for implementation from 1982 to 1985 and its objectives included training of qualified human resources for higher education teaching and research activities, and techniques to meet demands from both public and private sectors, similar to the objectives already described in PNPG I. Thus, the focus of this Plan II was to minimize the adverse effects of institutional and regional heterogeneities, i.e. to strengthen the regions considered poorer and which lacked the required human resources to cope with the fundamental issues of the socioeconomic reality.

The sources of funding are mentioned in the Plan as essential for the contribution to the National Postgraduate Policy, being crucial to complement the institutions' budgetary needs. However, they also became sources of instability because they supported and supplemented resources in a selective manner, using criteria not always recognized by the academic community. Such instability would also come from some slowness in appraising the requests for funds and grants. In addition to the resources-related issue, it can be seen in this Plan that research works at the postgraduate level was growing in number and quality, and discussions about mechanisms to measure its quality began to gain grounds.

PNPG III (BRASIL, 2016b) in turn was expected to be implemented from 1986 to 1989, during the government of President José Sarney. As a diagnosis, it pointed out that there was not a sufficient number of scientists in the country that could achieve in the short term full scientific and technological capacity. So, an aggressive program to develop qualified human resources was essential, aiming to economic, scientific and technological independence. To the common goals of the two previous plans, namely the institutionalization of postgraduate education, the development of top level personnel and the improvement of postgraduate courses, it was added other objectives related to the expansion of research programs in the universities and the integration of postgraduate courses to the National System of Science and Technology. In this period, there was a considerable expansion of postgraduate courses: from 370 programs registered for master's degree and 89 for doctor's degree, they rapidly reached 787 and 325, respectively (BRASIL, 2016b).

With respect to quality, the first appraisals of the postgraduate courses were made using quantitative indicators and qualitative criteria, which pointed to the need for improvements in the programs, in the qualification of faculty members, the need to review and implement new curricular structures, improvements in the definition and development of research activities, increase of scientific production by the academic staff, and improved quality of dissertations and theses that were developed in the scope of different programs. It is worth mentioning the National Education Guidelines and Framework Law (Lei de Diretrizes e Bases da Educação - LDB) of 1996 (BRASIL, 2017), which establishes that one third of the universities' academic staff should have a master's or PhD degree. Thus, the LDB stimulated the scientific and technological development of teachers and researchers and the increase of postgraduate programs in both public and private institutions.

It should be noted that in the mid-1990s, along with the LDB creation, CAPES adopted the CAPES' Evaluation Model. This model, according to Bianchetti and Sguissardi (2009), considers much more what a professor-researcher produces than the quality or the social, scientific and public benefit of what is actually produced, leading to the so-called academic productivism. For the authors, the adoption of this evaluation model had its genesis concomitant to the Bologna Process (1999) and the Sorbonne Declaration (1998). These processes were concerned with the competitiveness of the European university education system and disputes for the higher education market. This is how the academic or scientific productivism, articulated with evaluation processes, gained special importance, because Brazil at that time stood out among the emerging countries and in the support to central countries in times of mundialization of financial capital (SGUISSARDI, 2008). Thus, the development of Brazilian postgraduate programs, especially in the mid-1990s, was associated with the State reconfiguration, resulting in reduced funds for research combined with a scientific overproduction that necessarily did not present the expected research quality or the fulfillment of any country' social demand. It should also be noted that the faculty' scientific production has been strongly encouraged towards internationalization (SILVA; SILVA; MOREIRA, 2014), by valuing publication of articles in journals/periodicals indexed on international databases. So, elements such as the impact of a given journal and number of quotes reach the academic field, showing the neoliberal logic imposed to the production of knowledge, which, in turn, becomes a commodity. After more than one decade later, the PNPG IV (from 2005 to 2010), during Lula's 
government, proposes maintaining the achievements of the National Postgraduate System (SNPG). (BRASIL, 2016c). The main objective of PNPG IV is focused on the expansion of the System and in increasing the number of postgraduate students. CAPES would be responsible for assuring quality, through the coordination of the national postgraduate policies. It can be seen that from 1976 to 2004, the number of stricto sensu courses recommended by CAPES rose to 2,993, and the public sector continued to be responsible for the provision of master and doctorate courses, accounting for more than $80 \%$ of total supply. Resources for postgraduate activities are also discussed in this Plan, wherein is stated that, in addition to Sectorial Funds, it is important to provide other resources to support researchers in regions of "less critical mass" and the expansion of emerging research groups with high competence and requiring institutional support.

Finally, we have the PNPG V (from 2011 to 2020), which has as core objective to proceed with the plans and, in this regard, we can say that its focus is on the expansion of SNPG, creation of a national research agenda, improvement of the evaluation system, multi-, inter- and/or trans-disciplinary activities, and support to diverse educational levels. This Plan consists of an instrument of public policies for the purposes of "expanding, strengthening and improving the SNPG" (BRASIL, 2016d, p. 293). These objectives are vitally important because it is through SNPG that the interaction between universities and society can be strengthened.

On the other hand, it shows the enhancement of a historical support policy aimed to fulfill market interests through strategies focused on training human resources to meet such needs, such as, for instance, encouraging partnerships with the private sector. Such direction is described in all plans, re-stated and enhanced by the Law for Technological Innovation (Lei de Inovação Tecnológica), which aims to ensure innovation by means of association with diverse sectors and more interaction between university and enterprises. This means placing the university and its researchers in the condition of managers to raise funds in the marketplace in exchange for the provision of innovation services. It thus constitutes the materialization of what Sguissardi (2009) calls entrepreneurial immediacy in the field of science and technology, jeopardizing the university autonomy and characterizing contemporary universities as subordinates to the industrial policy and the interests of the industrial sector. Thus, the strategic driver, as part of the National Research Agenda, will be structured around incentives to some areas, aiming to a uniform growth and, therefore, inhibiting differences, plurality.

\section{National postgraduate policy and Social Work}

From the above, one can point out some key issues, especially relating to Human and Social Sciences, among them Social Work (AMARAL, 2012). The academic maturity achieved by Social Work is expressed in its recognition as an area of knowledge since 1980, with the expansion of stricto sensu postgraduate courses. The advances in professional training at the postgraduate level since the 1980s attest such academic maturity via the production of consistent, critical, broad, plural and contemporary literature (ABEPSS, 2014). This process began in the 1950s and 1960s and passed through all stages of construction and consolidation of an ethical-political project, expressed in the "strategic social direction of the profession and the process of professional renewal" (NETTO, 1996, p. 109). In this context, postgraduate education in Social Work is historically situated. Its role was crucial to overcoming the positivist bias "that determined the separation between thinking and acting, between building knowledge and intervening in social reality" (YAZBEK; SILVA, 2005, p. 42). The inclusion of Social Work researchers in the Brazilian support agencies (CNPq and CAPES) occurred in the decade of 1980. Evaluation carried out by CAPES has made possible the recognition of Social Work postgraduate courses, reaching levels of excellence and consolidated nationally and internationally. The number of researches and production of knowledge has increased and conferred expertise to the area.

Intellectuals such as Setubal (1995), Faria (2003), Kameyama (2004), Carvalho and Silva (2005), Lara (2007, 2008), Sposati (2007), Bourguignon (2005, 2007, 2008), among others, point to the importance of postgraduate programs to leverage knowledge production and research in Social Work. The importance of postgraduate education under critical inspiration in this area is highlighted by Guerra (2011), to the extent that it would hinder hegemony both in knowledge production and research, making Social Work a current and recognized interlocutor in the broad field that encompasses Social Sciences, "which today has hegemony in the production of knowledge and research, responsible for the renewal of the professional image and for making Social Work contemporary at its time and a recognized interlocutor in the field of social sciences" (GUERRA, 2011, p. 126). Such recognition remains materialized in the vast production of books, articles and book chapters, as well as in theses and dissertations resulting from scientific research developed by teachers and students and promoted by research groups connected to stricto sensu postgraduate programs in Social Work. Likewise, in the scope of Applied Social Sciences, particularly in Social Work, there have been advances endorsed by the last triennial evaluation reports and by significant intellectual production, in 
conformity with the reality movement (AMARAL, 2012). However, such reviews also discuss the challenges faced by teachers and students in postgraduate programs.

Thus, discussions about knowledge production and the role of such knowledge in society in a globalized context become vital, especially when one considers economic market integration, the possibilities of scientific and technological communication and the relations that make up this articulation between economies. Thus, knowledge becomes key in this process (MENDES et al., 2005). On these bases, innovations and technological processes become vital conditions for the economic development, which in turn becomes a condition for the production of knowledge in an intrinsically articulated and dependent dynamics. The State is responsible for seeking articulations to meet these new demands and, according to Mendes et al. (2005), the State begins to take on new roles with respect to the alignment and even the implementation of the relationships established between enterprises and universities. This alignment in turn has implied and still implies the regulation of the relationships and also the definition of the objectives of researches that will be carried out, which should be guided by an attempt to solve social and economic problems. This strategy of articulation between the State, university and enterprises, named triple propeller, demands changes in research management and in knowledge production, which have been underlined by business pressure. Shifts in knowledge production towards practical outcomes change the historical conduction of the scientific and technological practices adopted by universities. Thus, scientific and technological practices result from and are governed by alliances for co-production of knowledge by several subjects, derived from research projects and major degree requirements, costs inclusion, safety and social relevance. The new articulation often influences and changes the traditional quality criteria, requiring modifications and huge challenges to postgraduate programs, given the refunctioning of the university role and knowledge itself.

Revisiting the documents that make up the Postgraduate Plans is vital to knowing their rhetoric and premises and the bases that effectively contributed to the implementation, consolidation and expansion of Brazilian Stricto Sensu postgraduate programs. When one understands the meaning of PNPG IV in the evolution of postgraduate education, although it is not yet a document in its final version, it is a significant milestone in the implementation of various recommendations and changes made by CAPES' directors, such as raising the national standards to international standards, the system expansion, diversification of the postgraduate model, changes in the evaluation process and international recognition of postgraduate activities. The proposed goals are based on flexibilization principles, competitiveness and raising the evaluation standards, and aim to: expansion of the national postgraduate system and maintenance of its academic quality; reduction of regional inequalities in the postgraduate programs supply and performance; greater institutional commitment of postgraduate programs to graduation, aiming to the improvement and renewal of this educational level (BRASIL, 2004). Reforms on education were added to these measures, with significant effects on the Brazilian postgraduate model, such as the regulation of professional master programs and distance-learning postgraduate courses, controversial issues in the area of Social Work. These questions are reaffirmed in PNPG V (2011-2020), where

This strategy of articulation

between the State, university and enterprises, named triple propeller, demands changes in research management and in knowledge production, which have been underlined by business pressure. Shifts in knowledge production towards practical outcomes change the historical conduction of the scientific and technological practices adopted by universities. the strategic drive is secured via the development of a national research agenda, which proposes topics considered vital to the country (BRASIL, 2016d). In this regard, it describes the drivers and development of some areas in detriment of others, the latter comprising the Applied Social Sciences and, more specifically, Social Work. One of the issues that arise then is to consider the background of such strategic driver, its meaning. Mendes and Almeida (2014) point to the trend in Social Work research based on requests to CNPq. In this regard, the authors asserted the difficulties encountered in including the area in the sociotechnical division of knowledge. This means that Social Work is not included in the priority areas considered top areas for development. Examples of this condition can be found in the reduced number of researchers and scholarship students, in the meager funds allocated to the Social Work postgraduate programs for the development and 
research increase in this field. In addition, it should be emphasized that teachers have been increasingly trapped with the metrics and the exorbitant productivism required in the evaluation processes and also with the demand that he or she assumes the role of entrepreneur via associations with the private sector, seeking viability for the requested research funding. This prevents his or her full dedication to research activities and supervision of postgraduate students, which in turn will lead to reduced quality of the courses, which, for not meeting the required quality standards, lose funds. So, from researcher and provider of new knowledge that might fulfill effective social demands, as described in the abovementioned Plans, researchers have become fundraisers, service providers, hostages of enterprises in their attempt to obtain complementary remuneration to meet their needs in view of the low wages paid to them.

\section{Directions of knowledge production: there is a stumbling block on the way}

In this context, it is not wrong to state that CNPq and CAPES mainly have the mission to implement science and technology actions in Brazil, and because of these institutions, programs and projects that supported the research infrastructure in the country have been conceived and prospered. In addition, it should be noted that they guided and contributed to shape the beginning of the National Science, Technology and Innovation System as existing today, and the creation of the Ministry of Science and Technology, setting up CNPq in the Esplanade of Ministries in the representation of the science-genesis of CNPq. As with CPNq, FINEP also contributed to the Ministry of Science and Technology, and since the last decade it has been one of the main agents that foster and the support the country's technological innovation. The strategy for the articulation between the State, universities and enterprises, called triple propeller, requires changes in research management and knowledge production. As mentioned before, in PNPG V (2011-2020), the strategic driver, by means of the development of a national research agenda that proposes topics considered important to the country (BRASIL, 2016d), brings in its core the promotion and development of some areas in detriment of others, in this case those comprising Applied Social Sciences and, more specifically, Social Work. This fact perpetuates not only the regional asymmetries but also in the scope of knowledge production. It should be noted that the work developed by teachers and students often takes place in the university's premises, in the public space and with the support of the State. The students who receive scholarships from enterprises and who are part of the so-called "public/private partnership" arrangement, defend private interests and must be competitive, so they run counter to the purposes of this area.

The progressive economic contingencies faced by universities and the Brazilian public sector point to a period of severe difficulties. Funding cuts to universities hit their entire operations because this affects the costing and investments of institutions that depend on these funds to manage their installed capacity. Estimates indicate that budget cuts may trigger a very serious crisis in the production of knowledge, in the continuity of postgraduate programs, research works as well as in the continuity of undergraduate extension programs and assistance to students. Payments to outsourced workers, purchase of equipment, among other issues that make up the daily routine of the academic world are hardly hit by such downturn (LAMPERT; PINHEIRO, 2016). In addition, there are also structural changes included in government plans relating to changes in the hierarchy of institutions that are vital for the technological advancements. An example is the decreased autonomy of the Ministry of Science and Technology, CNPq, CAPES, FINEP, and other support agencies, the main agents that stimulate and finance research and technological innovation in the country.

The increased public disbursements to the private sector clearly shows the inversion of investments of public funds, legitimated by changes in the Brazilian laws and fiscal adjustments that stimulate this process. The Student Financing Fund (FIES), a program that was created by the Ministry of Education (MEC) to grant funds to students enrolled in non-free higher education courses is an example of the protectionism inversion to the private sector. In 2010, the percentage of students using FIES was 6\%, and in 2014 it already exceeded 40\% (THOMAZ, 2015). In short, the importance of PNPGs (I, II, III, IV, V) can be stated as "the key for explanation of designing a university project under a developmental perspective" (AMARAL, 2012, p. 232). Such perspective, historically, is leading a new style of knowledge production, based on the triple propeller (TRIGUEIRO, 1999), developed in the articulation between the State, university and enterprise. In addition, there is the neoliberal clash enforced via the creation of Proposed Constitutional Amendments (PEC) with the purpose of supporting the economic activity that unrestrictedly benefits the consolidation and spoliation of capital to the detriment of guarantees against social exclusion and restrictions. This context is marked by the hegemony of financial capital, whose ideological orientation is neoliberalism, which is widespread in the global political scenario. This is a crucial issue for Social Work, whose "professional project is the result and expression of a wide movement for democratization of society and uncompromising defense of human rights" (IAMAMOTO, 2007, p. 226). In this regard, there are numerous challenges faced by postgraduate education and knowledge production in the 
scope of Social Work and Human and Social Sciences which, according to Simionatto (2005), are blended with serious financial difficulties, uncertainties, insecurity, weakening of loyalties and impoverishment of coexistence.

\section{Final considerations}

The development of Brazilian research and postgraduate education, in general, had its objectives, goals and scopes devised by the National Postgraduate Plans. These plans were vitally important to think up guidelines for Brazilian postgraduate programs, based on the creation of a National Postgraduate System that could also combine growth and quality. Concerning Social Work, it also through postgraduate programs that this area of knowledge finds recognition, culminating the consolidation process of its ethical-political project. However, what is seen today is the production of knowledge guided by national research agendas which ultimately determine which are the objects of knowledge, ruling it.

So, by means of strategic drivers there effectively are a programmed selectivity of knowledge production, whose fundamentals are seated on the triple propeller, via entrepreneurial pressure, the State weakening and further corroborated by the Proposed Constitutional Amendments which, in general, institutionalize the legalization of regress and withdrawal of social rights. Thus, the structural and institutional changes in the coordination of the educational areas, research and postgraduate activities pose huge challenges to Science and knowledge production which, in this context, lie between a disaster or bankruptcy of the Brazilian postgraduate education. Privileging solid education, not accepting passively the commodifying process, the speeding up and banalization of professional education: is it possible? How to prioritize, in this scenario overwhelmed by norms, directives and policies, the production of knowledge with social relevance and which actually meet the needs and interests of Society and is at service of the working class, social movements and struggles? ABEPSS, a scientific Brazilian association of social workers, has contributed to make postgraduate education more organic in this relationship, supporting initiatives based on the solidarity between programs with the purpose of supporting and boosting those that are more fragilized by this perverse logic. Current challenges are huge, among them the impacts of the Brazilian university counter reform in the context of capitalist restructuring.

Regarding research, it is necessary to conceive indicators of social impact of the knowledge produced in postgraduate courses and its social function, and to question the importance of research works and how they are connected with the interests of society. It is necessary to discuss the vehiculation and socialization of scientific production in the field of Social Work, in order to allow visibility to individual and collective social subjects, often subjects of the investigations that are carried out. As an internationalization measure, we could emphasize the privileged interlocution established between the Brazilian Social Work and the Latin American Social Work in building a Critical Social Work, strengthening alliances with the countries of these territories in cooperation arrangements. In addition, tactics and strategies to face the trends of speeding up knowledge, among them Professional Master's Degree, a demand that has been made by CAPES for this area since the 2000 s, which at that time was bravely opposed by postgraduate programs in Social Work, for considering that it might favor the commodifying process of postgraduate education, impoverish and fragilize the area compared to the others, leading to the extinction of academic master courses. In addition, a key issue is related to the knowledge produced in the formulation, management, implementation and evaluation of social policies and in coping with the growth-inequality binomial (GUERRA, 2011). However, it is imperative to break the bureaucratic barriers imposed by support agencies, ruled and sustained by an untouchable technological system that maintains a system of records that does not express the progress achieved in the field of Social Work. Finally, it should be mentioned how Social Work is organized and located in CNPq, together with the Psychology committee, which contributes to more scarcity of the already insufficient resources available for the area. In addition to these difficulties are those resulting from the changes already imposed by PNPG IV, based on flexibilization, competitiveness, essentially-quantitative evaluation standards and oriented to productivism. For Social Work, it means acknowledging that "there is a stumbling block on the way", expressed in the immediacy of social life, permeated and driven by the voracity of a new offensive of the financial market, requiring that the area restate and ensure the principles and social direction of knowledge, whose centrality is the essence in the construction of the destinies of humanity and human emancipation.

\section{References}

AMARAL, A. A política nacional de pós-graduação e suas relações com o Serviço Social. Revista Katálysis, Florianópolis, v. 15, n. 2 , p. 230-238, jul./dez. 2012. 
ASSOCIAÇÃO BRASILEIRA DE ENSINO E PESQUISA EM SERVIÇO SOCIAL. Contribuição da ABEPSS para o fortalecimento dos Programas de Pós-graduação em Serviço Social no BRASIL. ABEPSS: Brasília, 2014.

BALBACHEVSKY, E. Processos decisórios em política científica, tecnológica e de inovação no Brasil: análise crítica. Centro de Gestão e Estudos Estratégicos, São Paulo, p. 01-37, 2010.

BIANCHETTI, L.; SGUISSARDI, V. (Orgs.). Dilemas da pós-graduação: gestão e avaliação. Campinas: Autores Associados, 2009. BOURGUIGNON, J. A. A particularidade histórica da pesquisa no Serviço Social. 2005. 342 f. Tese (Doutorado em Serviço Social) - Pontifícia Universidade Católica de São Paulo, São Paulo, 2005.

. A particularidade histórica da pesquisa no Serviço Social. Revista Katálysis, Florianópolis, v. 10, n. especial, p. 46-54, 2007.

. A centralidade ocupada pelos sujeitos que participam das pesquisas do Serviço Social. Revista Textos \& Contextos, Porto Alegre, v. 7 n. 2, p. 302-312, 2008.

BRASIL. Coordenação de Aperfeiçoamento de Pessoal de Nível Superior. II Plano Nacional de Pós-Graduação - PNPG $1986-1989$. Brasília, DF: CAPES, 2004.

Ministério da Educação e Cultura. Conselho Nacional de Pós-graduação. Departamento de Documentação e Divulgação. I Plano Nacional de Pós-Graduação (1975-1979). 2016a. Disponível em:

<https://www.capes.gov.br/images/stories/download/editais/__PNPG.pdf >. Acesso em: 28 out. 2016. . Coordenação de Aperfeiçoamento de Pessoal de Nível Superior. III Plano Nacional de Pós-graduação (1886-1989). 2016b.

Disponível em: 〈https://www.capes.gov.br/images/stories/download/editais/III_PNPG.pdf〉. Acesso em: 01 nov. 2016.

. Coordenação de Aperfeiçoamento de Pessoal de Nível Superior. IV Plano Nacional de Pós-graduação (2005-2010). 2016c.

Disponível em: <https://www.capes.gov.br/images/stories/download/editais/III_PNPG.pdf〉. Acesso em: 03 nov. 2016.

. Coordenação de Aperfeiçoamento de Pessoal de Nível Superior. V Plano Nacional de Pós-graduação (2011-2020). 2016d.

Disponível em: <https://www.capes.gov.br/images/stories/download/Livros-PNPG-Volume-I-Mont.pdf〉. Acesso em: 02 nov. 2016.

. Ministério da Educação e Cultura. Lei n. 9.394 de 20 de dezembro de 1996. Diretrizes e Bases da Educação Nacional (LDB).

Disponível em: <http://www.cpt.com.br/ldb/lei-de-diretrizes-e-bases-da-educacao-completa-interativa-e-atualizada> Acesso em: 25 fev. 2017.

CARVALHO, D. B. B.; SILVA, M. O. S. (Orgs.). Serviço Social, pós-graduação e produção de conhecimento no Brasil. São Paulo: Cortez, 2005.

CHAMLIAN, H. C. Estudo da organização departamental nas universidades mantidas pelo governo do estado de São Paulo. Relatório de Pesquisa. Revista Faculdade Educação, São Paulo, n.10, v. 1, p. 41-124, jan./jun. 1984.

FARIA, S. Produção de conhecimento e agenda socioprofissional no Serviço Social Brasileiro. 2003. 224 f. Tese (Doutorado em Serviço Social) - Programa de Estudos Pós-graduados em Serviço Social, São Paulo, 2003.

GUERRA, Y. A. D. A pós-graduação em Serviço Social no Brasil: um patrimônio a ser preservado. Temporalis, Brasília/DF, ano 11, n. 22, p. 125-158, jul./dez. 2011.

IAMAMOTO, M. V. O Serviço Social em tempo de capital fetiche: capital financeiro, trabalho e questão social. São Paulo: Cortez, 2007. KAMEYAMA, N. O papel da pós-graduação e da pesquisa na formação profissional. Temporalis, Brasília/DF, v. 8, p. 33-76, 2004. LAMPERT, A.; PINHEIRO, M. Contingenciamento coloca em risco funcionamento das universidades. Adverso, Porto Alegre, n. 221, p. 49-54, jul./ago. 2016.

LARA, R. Pesquisa e Serviço Social: da concepção burguesa de ciências sociais à perspectiva ontológica. Revista Katálysis, Florianópolis, n. 10, p. 73-82, 2007.

. A produção do conhecimento em Serviço Social: o mundo do trabalho em debate. Tese (Doutorado em Serviço Social) Faculdade de História, Direito e Serviço Social da Universidade Estadual Paulista Julio de Mesquita Filho, Franca, 2008.

MENDES, J. M. R. et al. A pesquisa, a produção e a divulgação do conhecimento dos Programas de Pós-Graduação na área de Serviço Social. In: CARVALHO, D. B. B.; SILVA, M. O. S. (Orgs.). Serviço Social, pós-graduação e produção do conhecimento no Brasil. São Paulo: Cortez, 2005. p. 69-142.

MENDES, J. M. R.; ALMEIDA, B. L. F. de. As recentes tendências da pesquisa em Serviço Social. Serviço Social e Sociedade, São Paulo, n. 120, p. 640-661, out./dez. 2014.

NETTO, J. P. Transformações Societárias e Serviço Social. Notas para uma análise prospectiva da profissão no Brasil. Revista Serviço Social e Sociedade, São Paulo, n. 50, p. 87-132, abr. 1996.

SANTOS, B. S. O papel da produção do conhecimento na transformação social. In: SEMINÁRIO INTERNACIONAL "O PAPEL DA SOCIEDADE CIVIL NAS NOVAS PAUTAS POLÍTICAS”, 2003. São Paulo. Anais... . São Paulo: ABONG, 2003.

SETUBAL, A. A. Pesquisa em Serviço Social: utopia e realidade. São Paulo: Cortez, 1995.

SGUISSARDI, V. Regulação estatal versus cultura da avaliação institucional? Avaliação, Campinas, v. 13, n. 3, p. 857-862, 2008.

. A Universidade Brasileira no século XXI: Desafios do presente. São Paulo: Cortez, 2009.

SILVA, J. V. P.; SILVA, L. L. C.; MOREIRA, W. M. Produtivismo na pós-graduação. Nada é tão ruim que não possa piorar. É chegada a vez dos orientandos. Movimento, Porto Alegre, n.4, p. 1423-1445, 2014.

SIMIONATTO, I. Os desafios na pesquisa e na produção do conhecimento em Serviço Social. Temporalis, Recife, ano 5, n. 9, p. 07-21, jan./jun. 2005.

SPOSATI, A. Pesquisa e produção de conhecimento no campo do Serviço Social. Revista Katálysis, Florianópolis, v. 10, p. $15-25,2007$. 
THOMAZ, J. Gil Vicente alerta para a privatização do ensino superior. Adverso, Porto Alegre, n. 217, p. 42-45, nov./dez. 2015. R. Katál., Florianópolis, v. 20, n. 2, p. 175-183, maio/ago. 2017 ISSN 1982-0259 YAZBEK, M. C.; SILVA, M. O. S. Das origens à atualidade da profissão: a construção da Pós-Graduação em Serviço Social no Brasil. In: CARVALHO, D. C. B.; SILVA, M. O. S. (Orgs.). Serviço Social, Pós-Graduação e Produção do Conhecimento no Brasil. São Paulo: Cortez, 2005. p. 25-49.

\section{Nota}

1 "The academic chair model refers to the faculty position occupied by one single individual and specifically related to a certain field of knowledge more or less broad, but increasingly oriented to specialization. The head of the chair is the 'academic lens', careful with his or her unique position and prerogatives, the exclusive 'owner' of an area of study to which he/she was appointed (selected by public exam or not)"'(CHAMLIAN, 1984, p. 41).

\section{Jussara Maria Rosa Mendes}

jussaramaria.mendes@gmail.com

Doctoral degree on Social Work from the Pontifical Catholic University of São Paulo (PUC/SP)

Professor of the Social Work Course, Federal University of Rio Grande do Sul (UFRGS)

\section{UFRGS}

2600 Ramiro Barcelos st., Psychology Institute, Floresta

Porto Alegre - Rio Grande do Sul - Brazil

Zip code: $90.035-002$

\section{Andréia Mendes dos Santos}

andreiam72@gmail.com

Doctoral degree on Social Service from the Pontifical Catholic University of Rio Grande do Sul (PUCRS)

Professor at the Humanities School and Postgraduate Program in Education (PUC/RS)

\section{PUCRS}

6681 Ipiranga av., 15 building - room 377, Partenon

Porto Alegre - Rio Grande do Sul - Brazil

Zip code: $90.619-900$

\section{Rosangela Werlang}

rosangelawerlang@gmail.com

Doctoral degree on Social and Institutional Psychology from the Federal University of Rio Grande do Sul (UFRGS)

Visitor Researcher (UFRGS/CNPq)

\section{UFRGS}

2777 Ramiro Barcelos st., Health Department 1, room 318, Santana

Porto Alegre - Rio Grande do Sul - Brazil

Zip code: 90.035-007 